\title{
PENGEMBANGAN BAHAN AJAR FISIKA BERBASIS KONTEKSTUAL DENGAN MENGINTEGRASIKAN KEARIFAN LOKAL UNTUK MENINGKATKAN PEMAHAMAN KONSEP FISIKA PADA MAHASISWA
}

\author{
Muhammad Satriawan'), Rosmiati' ${ }^{2)}$ \\ 1), 2) Dosen Program Studi Pendidikan Fisika STKIP Bima \\ E-mail: satriawan.stkipbima@gmail.com \\ E-mail: rosebiru1@gmail.com
}

\begin{abstract}
Abstrak: Penelitian ini adalah penelitian pengembangan yang mengembangkan bahan ajar fisika berbasis kontekstual dengan mengintegrasikan kearifan lokal. Untuk lebih jauh penelitian ini sebagai dasar pengembangan buku ajar Fisika yang bernilai ekonomi tinggi. Penelitian ini bermaksud untuk meningkatkan pemahaman konsep fisika peserta didik. Bahan ajar dikembangkan menggunakan model $R \& D$ dengan model pengembangan yang digunakan adalah model Borg \& Gall (1989) dan Kemp \& Dayton (1985) yang terdiri atas; (1) penelitian dan pengumpulan data melalui survei, (2) perencanaan, (3) penyusunan bahan ajar cetak dalam bentuk lembar kerja siswa, (4) uji validitas pakar, (5) revisi produk, (6) uji coba lapangan skala kecil, (7) revisi produk, (8) uji coba lapangan skala luas, (9) revisi produk final, dan (10) diseminasi dan implementasi. Uji coba bahan ajar dilakukan mahasiswa program studi pendidikan fisika dengan model tes one group pretest-posttes design. Dan berdasarkan hasil analisis dari data validasi dan uji coba bahwa bahan ajar yang dikembangkan menunjukkan kriteria"sangat layak" untuk digunakan serta dapat meningkatkan pemahaman konsep fisika mahasiswa pada perkuliahan fisika dasar.
\end{abstract}

Kata kunci: Pengembangan bahan ajar fisika, pembelajaran kontekstual, kearifan lokal, pemahamam konsep fisika.

Abstract: This research is a development research that develops teaching materials physics based contextual by integrating local wisdom. To further this research as the basis for the development of textbook physics of high economic value. This study intends to improve the mastery of concepts of physics students. Teaching materials developed using models of R \& D with develop model used is a model development Borg \& Gall (1985) and Kemp and Dayton (1985), which consists of; (1) research and data collection through surveys, (2) planning, (3) the preparation of teaching materials printed in the form of student worksheets, (4) test the validity of the expert, (5) product revision, (6) field trials small scale, (7) the revised product, (8) broad-scale field trials, (9) the revision of the final product, and (10) the dissemination and implementation. The trials conducted teaching materials student of physics education by test model one group pretest-posttes design. And based on the analysis of the data validation and testing that the teaching materials developed showing the criteria of "very feasible" to use and to improve the procurement of the concepts of physics students in basic physics lectures.

Keywords: Development of teaching materials physics, contextual learning, local wisdom, understanding of physics concepts

\section{PENDAHULUAN}

Dunia pendidikan memegang peranan penting dalam peningkatan SDM bermutu. Peningkatan mutu SDM dapat dilakukan melalui kegiatan pembelajaran yang berkualitas. Menurut kajian Sudarman (2007) menyatakan bahwa kegiatan pembelajaran sampai saat ini merupakan pilihan strategis untuk mencapai tujuan individual yang berkompeten. Namun, hal tersebut masih jauh dari harapan karena selama ini pembelajaran di sekolah masih cukup banyak yang bersifat meneruskan informasi dari pendidik kepada peserta didik. Apabila hal ini tidak segera diatasi melalui suatu inovasi pembelajaran yang memadai maka akan menjadi pengalaman buruk bagi peserta didik. Oleh karena itu, pembelajaran hendaknya memfokuskan pada proses transformasi dan tidak sekadar mentransfer pengetahuan begitu saja. Semua itu akan dapat dicapai dengan menyiapkan sarana/prasarana serta infrastruktur yang memadai sebagai pendukung utama dalam pembelajaran serta harus dimanfaatkan secara optimal.

Salah satu pendukung pembelajaran yang perlu dikembangkan saat ini untuk melengkapi sarana/prasarana yang telah ada adalah ketersediaan bahan ajar yang memadai. Dengan adanya bahan ajar yang memadai, peserta didik dapat belajar dan mendiskusikan materi ajar sebelum pembelajaran dimulai. Di samping itu, bahan ajar juga mampu memberikan tuntunan yang jelas mengenai kompetensi yang ingin dicapai oleh peserta didik. Walaupun ketersediaan bahan ajar fisika saat ini memang sudah banyak, akan tetapi kebanyakan bahan fisika yang ada 
masih kurang dapat dicerna oleh peserta didik khususnya di sekolah-sekolah yang letaknya luar kota atau pinggiran kota. Hal ini dikarenakan oleh gaya bahasa yang terlalu rumit, permasalahan yang diangkat tidak pernah dialami atau diketahui oleh peserta didik, gambar-gambar yang ditunjukkan kurang jelas dan cenderung gambar-gambar tersebut masih asing untuk peserta didik konsumsi. Berdasarkan hasil penelitian Japa (2013) bahwa peserta didik menyatakan sanggup ketika ditugaskan mencari sumber di perpustakaan atau internet. Tetapi, ada beberapa persoalan yang mereka temui, di antaranya: (1) peserta didik sering menemukan sumber yang materinya kurang valid (tidak lengkap); (2) penulis bahan (artikel) di internet sering tidak jelas terutama yang bersumber dari blog dan setelah dianalisis banyak ditemukan miskonsepsi; (3) peserta didik hanya mengambil materi yang mudah, sedangkan yang relatif sulit di buang karena tidak dipahami, sehingga takut menyajikan.

Widodo (2015) mengungkapan cukup banyak penelitian yang menghasilkan produk berupa buku siswa. Secara umum, berdasarkan amatan penulis saat sebgai pembimbing, reviewer, atau validator, buku yang dihasilkan dari karya penelitian cenderung: (1) berupa "kumupulan deskripsi pengetahuan"; (2) ditulis dengan program pengolah kata yang bukan khusu untuk publishing; (3) layoutnya kaku, membosankan, dan tidak menunjang perwajahan yang layak sebagai buku; (4) gambar/foto yang mengiringi "asal comot" tanpa editingfoto yang memadai dan (5) aspek kebenaran isi, bahasa dan penyajian yang kurang validasi.

Berdasarkan kondisi tersebut perlu dilakukan sebuah terobosan baru untuk menghasilkan bahan ajar yang menyajikan sumber bahan yang baik dan susunannya teratur, sistematis, bervariasi, serta kaya akan informasi. Di samping itu harus mempunyai daya tarik kuat karena akan mempengaruhi minat peserta didik terhadap bahan tersebut. Oleh karena itu, bahan ajar itu hendaknya menantang, merangsang, dan mengaitkan antara materi yang diajarkan dengan situasi nyata, sehingga dapat membantu peserta didik memahami materi pelajaran. Berdasarkan uraian tersebut salah satu solusi yang dapat dilakukan yaitu mengembangkan bahan ajar berbasis kontekstual. Pembelajaran kontekstual merupakan pembelajaran yang berorientasi pada penciptaan semirip mungkin dengan situasi "dunia nyata" peserta didik. Melalui pembelajaran kontekstual dapat membantu pendidik mengaitkan antara materi yang diajarkan dengan situasi nyata, sehingga dapat membantu peserta didik untuk memahami materi pelajaran. Dengan adanya bahan ajar yang memadai, peserta didik dapat belajar dan mendiskusikan materi ajar sebelum pembelajaran dimulai. Di samping itu, bahan ajar juga mampu memberikan tuntunan yang jelas mengenai kompetensi yang ingin dicapai oleh peserta didik.

Trianto (2011) menjelaskan bahwa dengan menerapkan prinsip pembelajaran kontekstual diharapkan pembelajaran akan lebih bermakna bagi peserta didik, karena peserta didik akan bekerja secara ilmiah dan mengalami sendiri bukan hanya mentransfer pengetahuan pendidik ke peserta didik. Dengan demikian bahan ajar yang dikembangkan akan dicantumkan permasalahan-permasalahan atau fenomena-fenomena fisika yang biasa terjadi atau sudah tidak asing lagi bagi peserta didik sehingga memudahkan peserta didik menerima atau menyerap materi pelajaran.

Namun permasalahan lainnya yang muncul saat ini adalah degredasi moral anak bangsa yang cukup siginfikan. Noor (2011) menyatakan bahwa arus modern semakin memengaruhi terkikisnya moral anak bangsa. Maka perlu dilakukan pembinaan watak sebagai salah satu cara untuk mengatasi krisis moral pada masa ini, baik dengan memaksimalkan fungsi sebagai pendidik tidak hanya sebagai pengajar maupun dengan media-media pendidikan serta bahan ajar peserta didik. Oleh karena itu, dalam pengembangan bahan ajar fisika selain berbasis kontekstual tetapi akan diintegrasikan dengan kearifan lokal sebagai solusi degredasinya mental anak bangsa. Pembinaan moral peserta didik menjadi bagian penting dalam tujuan pendidikan nasional kita, karena pendidikan bagian dari mata pelajaran yang ada dalam kurikulum pendidikan dasar dan menengah memiliki peran penting dan strategis dalam pembentukan mental dan jati diri bangsa. Dan pembelajaran yang bersumber pada nilai kearifan lokal juga penting bagi pengembangan diri peserta didik (Sartini, 2006).

Ridwan (2007) mengemukakan bahwa kearifan lokal dapat dipahami sebagai usaha manusia dengan menggunakan akal budinya (kognisi) untuk bertindak dan bersikap terhadap sesuatu, objek atau peristiwa yang terjadi dalam ruang tertentu. Dengan demikian dapat disimpulkan bahwa kearifan lokal merupakan seperangkat pengetahuan, nilai-nilai, perilaku, serta cara bersikap terhadap objek dan peristiwa tertentu di lingkunganya yang diakui kebaikan dan kebenarannya. Dengan mengintegrasikan kearifan lokal pada bahan ajar fisika yang berbasis kontekstual, diharapkan akan mempermudahkan peserta didik dalam memahami dan menerima pelajaran fisika. Selain itu, peserta didik dapat mengambil pelajaran dari fenomena-fenomena fisika yang dituangkan bahan ajar dalam bentuk pesan moral sebagai suatu kearifan lokal, sehingga pemahaman konsep fisika dan moral peserta didik menjadi lebih baik. Dan agar bahan ajar yang dikembangkan lebih mudah diterima oleh siswa sebaiknya diintegrasikan dengan aspek lain yang dapat 
membuat siswa tertarik dengan materi yang akan disampaikan. Salah satu contoh adalah kearifan lokal.

Ibrahim (2015) menyatakan bahwa mengintegrasikan kearifan lokal dalam aktifitas pendidikan dan pembelajaran sangat potensial untuk memunculkan suatu inovasi dengan kebaharuan. Pengintegrasian kearifan lokal ke dalam pendidikan dapat dilakukan dalam berbagai bentuk dan tujuan, antara lain: (a) kearfian lokal sebagai model, yang dapat menjadi teladan untuk ditiru dan diamalkan dalam kehidupan sehari-hari; (b) kearifan lokal sebagai konten/isi pelajaran yang dapat berperan sebagai contoh-contoh yang diajarkan; (c) kearifan lokal sebagai penginspirasi, yang memunculkan ide-ide baru di dalam pembelajaran.

Salah satu contoh dalam pelajaran fisika kearifan lokal sebagai model perilaku hidup seimbang yaitu dengan memvisualisasikan konsep gerak peluru terhadap sumbu XY, di mana arah sumbu Y menunjukan hubungan seseorang dengan Tuhannya (Hablumminallah) dan arah sumbu $\mathrm{X}$ menunjukan hubungan sesama manusia (Hablumminannas) yang senantiasa selalu dijaga. Dengan kata lain, hidup yang dimulai dari titik $0^{0}$ berangsur naik dan membentuk sebuah sudut elevasi tertentu (semakin menunju $45^{\circ}$, maka semakin menuju pada sebuah keselarasan hidup, di mana relasi antara sesama manusia dan sang pencipta seimbang) (Ibrahim, 2014).

Mengintegrasikan kearifan lokal pada pembelajaran yang kontekstual tentunya akan membantu pemahaman konsep fisika siswa. Dahar dalam Parno (2008) menyatakan bahwa pemahaman konsep dapat diartikan sebagai kemampuan siswa dalam memahami makna secara ilmiah, baik konsep secara teori maupun penerapannya dalam kehidupan sehari-hari. Pemahaman konsep merupakan bagian dari hasil dalam komponen pembelajaran. Dengan demikian pemahaman konsep merupakan bagian dari hasil belajar pada ranah kognitif. Belajar kognitif bertujuan memperbaiki pemahaman siswa tentang konsep yang dipelajari.

\section{METODE PENELITIAN}

Penelitian ini adalah penelitian pengembangan yang mengembangkan bahan ajar fisika berbasis kontekstual dengan mengintegrasikan kearifan lokal. Untuk lebih jauh penelitian ini sebagai dasar pengembangan buku ajar Fisika yang bernilai ekonomi tinggi. Penelitian ini bermaksud untuk meningkatkan pemahaman konsep fisika peserta didik. Bahan ajar dikembangkan menggunakan model $R \& D$ dengan model ujicoba one group pretest-posttes design. Model pengembangan yang digunakan adalah model Borg \& Gall (1989) dan Kemp \& Dayton (1985) yang terdiri atas; (1) penelitian dan pengumpulan data melalui survei, (2) perencanaan, (3) penyusunan bahan ajar cetak dalam bentuk lembar kerja siswa, (4) uji validitas pakar, (5) revisi produk, (6) uji coba lapangan skala kecil, (7) revisi produk, (8) uji coba lapangan skala luas, (9) revisi produk final, dan (10) diseminasi dan implementasi. Pada tahap penelitian dan pengumpulan data dilakukan studi bahan kajian fisika studi muatan kontekstual dalam fisika studi muatan kearifan lokal dalam fisika. Pada tahap perencanaan mengumpulkan referensi untuk bahan ajar, pemilihan program desain yang tepat, pemilihan layout yang menarik, dan menyiapkan bahan evaluasi dalam bahan ajar. Pada tahap penyusunan bahan ajar akan dihasilkan draft bahan ajar, yang kemudian pada tahap selanjutnya draft tersebut dilakukan uji validitas pakar dengan komposisi satu orang pakar bahan ajar fisika, satu orang pakar media dan satu orang praktisi (guru fisika).

Terdapat beberapa jenis instrumen yang digunakan dalam penelitian ini, yaitu: 1) lembar Penilaian bahan ajar, berupa instrumen penilaian digunakan untuk memastikan bahwa bahan ajar yang dikembangkan layak digunakan, antara lain: lembar penilaian validasi, tingkat keterbacaan dan lembar penilaian tingkat kesulitan bahan ajar; 2) Instrumen Tes, berupa Lembar penilaian yang sudah divalidasi dan dinyatakan valid dan selanjutnya digunakan sebagai Instrumen Tes Hasil Belajar (THB) siswa; dan 3) Instrumen Angket skala likert, dimaksudkan untuk mendapatkan tanggapan pengguna bahan ajar yang dikembangkan

Adapun tahapan pengembangan perangkat pembelajaran ini terdiri dari sembilan komponen sesuai dengan diagram alir pada Gambar 1 berikut:

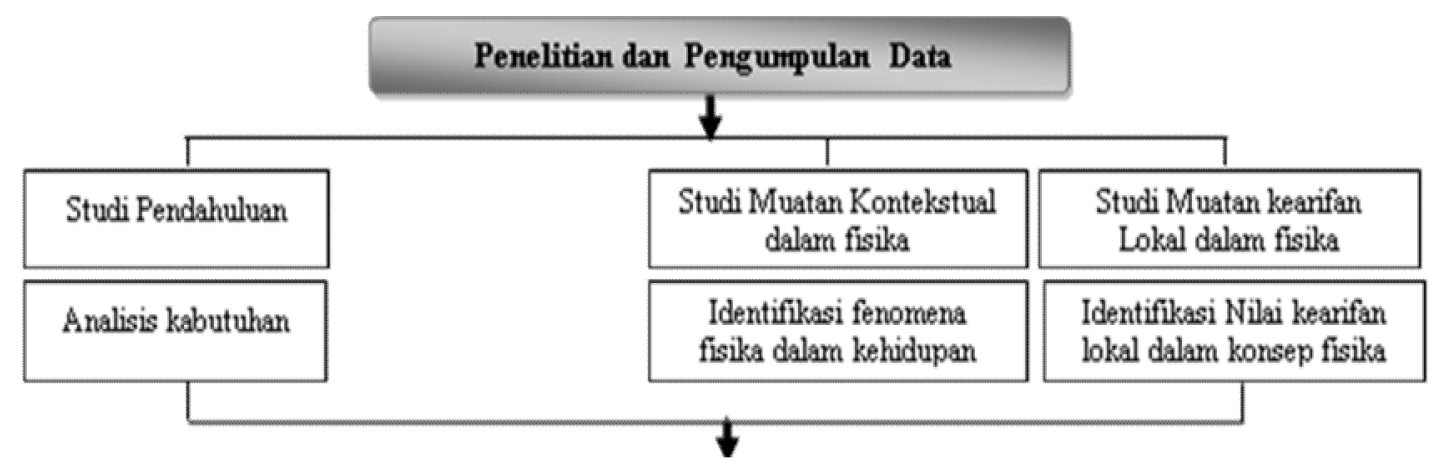




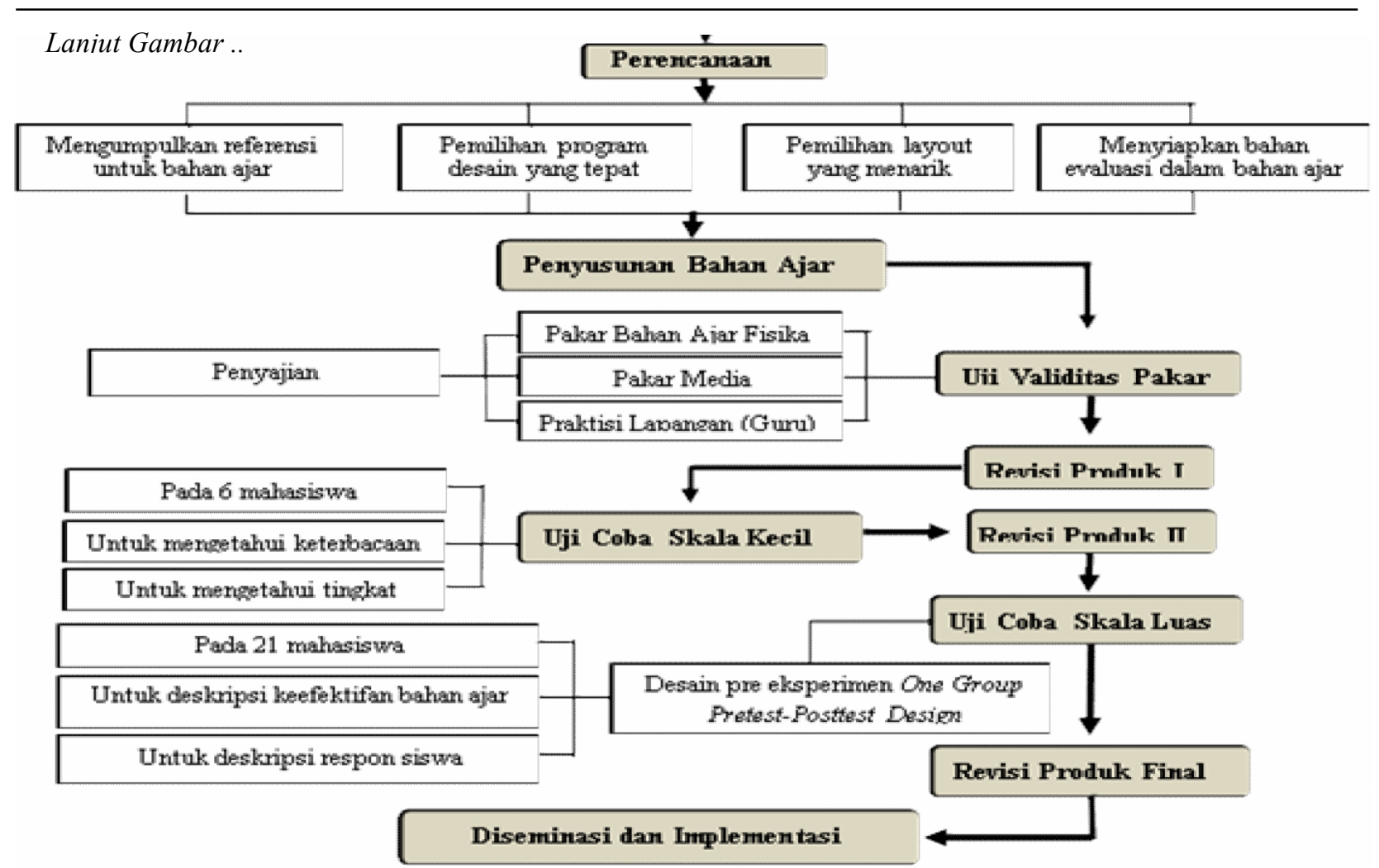

Gambar 1. Model Pengembangan Borg \& Gall (1989) dan Kemp \& Dayton (1985)

\section{HASIL PENELITIAN DAN DISKUSI}

Berdasarkan hasil analisis data dari angket yang disebarkan pada mahasiswa fisika semester I sebanyak 15 orang pada studi pendahuluan bahwa semuanya mahasiswa membutuhkan referensi baru untuk mempermudah pengusaan konsep fisika. Pada dasarnya mahasiswa membutuhkan pembelajaran yang kontekstual, baik dalam penyampaian konsep maupun soal-soal yang diberikan harus kontekstual juga.

Tabel 1. Hasil studi pendahuluan

\begin{tabular}{|l|l|l|}
\hline No & Aspek & Keterangan \\
\hline 1 & Referensi Baru & $\begin{array}{l}100 \% \text { sangat } \\
\text { dibutuhkan }\end{array}$ \\
\hline 2 & $\begin{array}{l}\text { Referensi yang } \\
\text { mempermudah pemahaman } \\
\text { konsep }\end{array}$ & $\begin{array}{l}100 \% \text { sangat } \\
\text { dibutuhkan }\end{array}$ \\
\hline 3 & $\begin{array}{l}\text { Bahan ajar yang } \\
\text { kontekstual }\end{array}$ & $\begin{array}{l}93 \% \text { sangat } \\
\text { dibutuhkan }\end{array}$ \\
\hline 4 & $\begin{array}{l}\text { Melibatkan kearifan lokal } \\
\text { pada bahan ajar }\end{array}$ & $\begin{array}{l}80 \% \text { sangat } \\
\text { dibutuhkan }\end{array}$ \\
\hline
\end{tabular}

Hasil dari analisis kebutuhan pada tabel di atas menunjukkan bahwa mahasiswa membutuhkan referensi baru yang mempermudah mereka untuk memahami konsep fisika. Setelah itu, dilanjutkan dengan penyususunan bahan ajar berdasarkan hasil kajian materi fisika, adanya muatan kontekstual dan kearifan lokal untuk memperkaya pengetahuan mahasiswa dengan menggunakan program adobe indesign dan memperhatikan pemilihan layout yang menarik sehingga dihasilkan sebuah bahan ajar untuk bab mekanika. Bahan ajar yang dihasilkan kemudian divalidasi oleh 3 orang ahli untuk mengetahui kelayakan isi, kebahasaan, penyajian dan kegrafikan (Widyoko, 2012).

Tabel 2. Rekapitulasi Hasil Uji Validasi Ahli

\begin{tabular}{|l|l|l|l|}
\hline Aspek & $\begin{array}{l}\text { Skor } \\
\text { rata-rata }\end{array}$ & Kategori & Keterangan \\
\hline $\begin{array}{l}\text { Kelayakan } \\
\text { isi }\end{array}$ & 3,62 & $\mathrm{~A}$ & Sangat layak \\
\hline Kebahasaan & 2,98 & $\mathrm{~B}$ & Layak \\
\hline Penyajian & 3,46 & $\mathrm{~A}$ & Sangat layak \\
\hline Kegrafikan & 2,98 & $\mathrm{~B}$ & Layak \\
\hline
\end{tabular}

Bahan ajar yang telah divalidasi selanjutnya direvisi sesuai dengan masukan dan saran yang disampaikan oleh validator ahli yang kemudian menghasilkan draft I. Adapun masukan dan saran yang diperoleh adalah perlunya memperbaiki tata bahasa dan gambar yang perlu diberikan efek agar terlihat dengan jelas. Selain itu, perlu dilakukan penambahan contoh soal yang berbasis kontekstual yang memuat kearifan lokal. Selanjutnya draft I dilakukan uji coba skala kecil pada 6 orang mahasiswa untuk mengetahui untuk mengetahui keterbacaan dan tingkat kesulitan bahan ajar. Selanjutnya direvisi berdasarkan hasil ujicoba skala kecil dan menghasilkan draft II yang kemudian diujicoba skala besar pada 21 mahasiswa. Hasil revisi dari ujicoba skala besar dihasilkan draft III atau produk final yang didesiminasi dan diaplikasikan pada 
perkuliahan. Berikut grafik data rata-rata hasil belajar mahasiswa pada pokok bahasan mekanika dengan menggunakan bahan ajar fisika berbasis kontekstual dengan mengintegrasikan kearifan lokal pada mahasiswa fisika STKIP Bima semester I tahun ajaran 2015/2016:

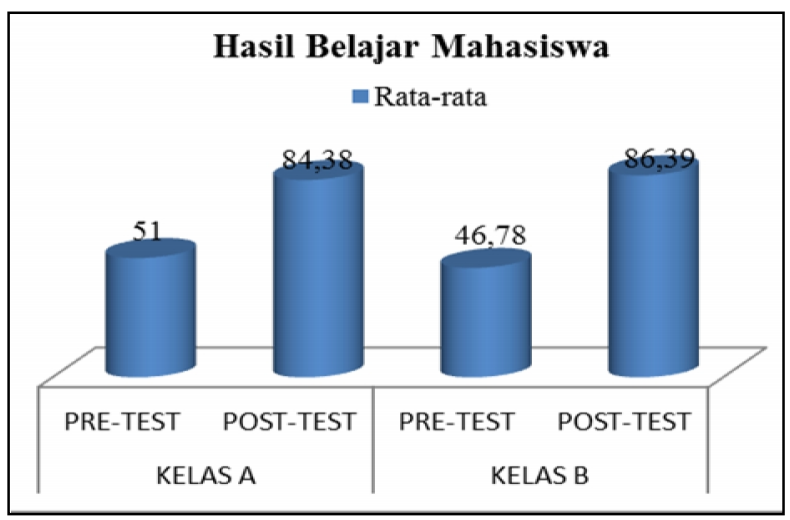

Gambar 2. Grafik Hasil Belajar Mahasiswa

Berdasarkan hasil belajar yang ditunjukkan oleh grafik pada gambar 2 di atas, terlihat bahwa nilai ratarata kelas $\mathrm{A}$ adalah 84,38 dengan kategori sangat tinggi dari nilai rata-rata pretest 51 . Begitu juga dengan kelas B nilai rata-rata klasikal adalah 86,39 dari nilai rata pretest hanya 46,78 . Hal ini menunjukkan bahwa adanya peningkatan pemahaman konsep fisika pada mahasiswa melalui perkuliahan yang menerapkan bahan ajar fisika berbasis kontekstual dengan mengintegrasikan kearifan lokal. Adanya peningkatan pemahaman konsep fisika pada mahasiswa diperjelas oleh N-Gain Skor pada grafik berikut:

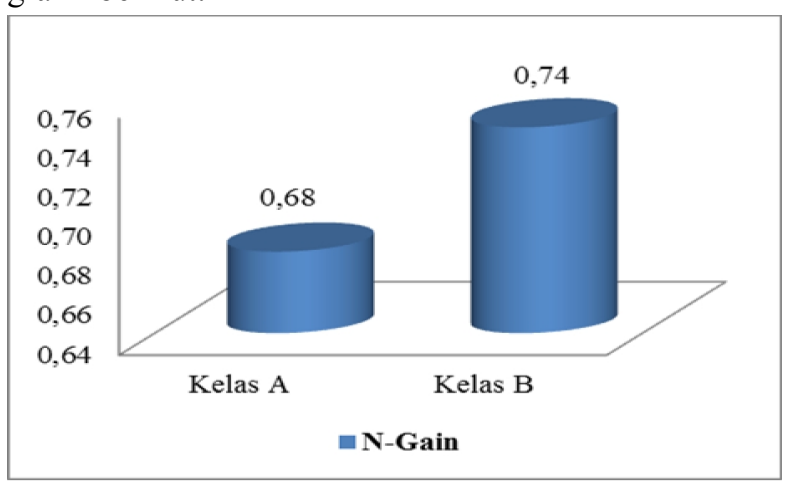

Gambar 3. Grafik hasil analisis N-Gain skor

Dari grafik di atas terlihat bahwa Kelas A memiliki NGain skor 0,68 kategori sedang. Hal ini menunjukkan bahwa, adanya peningkatan pemahaman konsep fisika yang pada mahasiswa. Berbeda dengan kelas B memiliki N-Gain skor 0,74 kategori tinggi. Hal ini dikarenakan oleh Kelas B hanya memiliki jumlah mahasiswa 18 orang sehingga suasana kelas sangat kondusif dan mahasiswa sangat antusias memperhatikan apa yang dijelaskan oleh dosen. Dari hasil diskusi peneliti dengan beberapa mahasiswa bahwa mahasiswa sangat tertarik dengan materi yang disampaikan dikarenakan hampir semua contoh soal atau soal-soal yang dalam bahan ajar merupakan isu-isu atau permasalahan yang pernah mereka hadapi. Selaras yang dikemukakan oleh Muchith (2008) bahwa pendekatan kontekstual merupakan pembelajaran yang bermakna dan menganggap tujuan pembelajaran adalah situasi yang ada dalam konteks tersebut, konteks itu membantu siswa dalam belajar bermakna dan juga untuk menyatakan hal-hal yang abstrak. Dan Ibrahim (2014) menjelaskan bahwa mengintegrasikan kearifan lokal dalam aktifitas pendidikan dan pembelajaran sangat potensial untuk memunculkan suatu inovasi dengan kebaharuan dan kearifan lokal sebagai penginspirasi, yang memunculkan ide-ide baru di dalam pembelajaran.

\section{KESIMPULAN}

Berdasarkan hasil penelitian dan pembahasan dapat disimpulkan bahwa bahan ajar berbasis kontekstual dengan mengintegrasikan kearifan lokal yang dikembangkan sangat layak untuk digunakan serta dapat meningkatkan pengusaan konsep fisika mahasiswa pada perkuliahan fisika dasar pada pokok bahasan Mekanika

\section{REFERENSI}

Bakry, N. (2011). Pendidikan Kewarganegaraan. Yogyakarta: Pustaka Pelajar.

Borg, W.R. \& Gall, M.D. (1989). Educational Research An Introduction. New York: Longman

Ibrahim, M. (2014). Inovasi Pembelajaran Sains Berbasis Kearifan Lokal. Dalam Makalah Utama Seminar Nasional "Sains dan Inovasi Pembelajaran Berbasis Kearifan Lokal" 22 November 2014 IKIP Mataram.

Japa, Gst. N. (2013). Pengembangan Buku Ajar Pendidikan Matematika III Berpendekatan Pendidikan Matematika Realistik dan Perubahan Konseptual. Laporan Penelitian. Undiksha.

Kemp, J.E. \& Dayton, D.K. 1985. Planning and Producing Instructional Media. Cambridge: Harper \& Row Publishers New York

Parno. (2008). Peningkatan Pemahaman Konsep Dasar Fisika Sekolah Mahasiswa melaui Pembelajaran Menggunakan Peta Konsep dan PBI. FOTON: Jurnal Fisika dan Pembelajaran. Jurusan Fisika FMIPA Uninersitas Negeri Malang. Vol. 12, No $1, \mathrm{pp}: 7-20$

Ridwan, N.A. (2007). Landasan Keilmuan Kearifan Lokal. P3M STAIN, Purwokerto. Vol 5. JanuariJuni 2007.

Saekhan, M. (2008). Pembelajaran Kontekstual. Semarang: Rasail

Sartini. (2006). Menggali Kearifan Lokal Nusantara Sebuah kajian Filsafat. http://filsafat.ugm.ac.id, 
diakses tanggal 30 April 2010.

Sudarman. (2007). Problem Based Learning: Suatu Model Pembelajaran untuk Mengembangkan dan Meningkatkan Kemampuan Memecahkan masalah. Jurnal Pendidikan Inovatif. Vol 2. No. 2. (6 halaman) .

Trianto. (2011). Model Pembelajaran Terpadu Konsep,Strategi dan Implementasinya Dalam Kurikulum Tingkat Satuan Pendidikan (KTSP). Jakarta : Bumi Aksara.
Widodo, W. (2015). Menjadikan karya akademik bernilai ekonomi. Dalam makalah utama seminar nasional "Mengubah Karya Akademik menjadi karya bernilai ekonomi tinggi”. Universitas Surabaya: 23 januari 2016.

Widyoko, S.E.P. (2012). Teknik Penyusunan Instrumen Penelitian. Pustaka Pelajar: Yogyakarta 